\title{
DEVELOPMENT OF COOPERATION BETWEEN CENTRAL ASIAN COUNTRIES AND CHINA IN ACCORDANCE WITH THE "ECONOMIC BELT OF SILK ROAD"
}

\author{
Ph.D. student Tleulina Aigerim \\ People's Republic of China, Hunan province, Xiangtan city, \\ Hunan Technical University of Science and Technology
}

DOI: https://doi.org/10.31435/rsglobal_ijite/31032020/6964

\section{ARTICLE INFO}

Received 28 January 2020

Accepted 15 March 2020

Published 31 March 2020

\section{KEYWORDS}

Economic belt of the Silk

Road,

the Asian Infrastructure

Investment Bank,

the Silk road fund,

"one belt - one way",

the commodity turnovers and etc.

\begin{abstract}
The Economic belt of the Silk Road project (hereinafter referred to as the "EBSR") has formed China's new long-term strategy "One belt - one way". With a view to the practical implementation of the EBSR initiative, China, in cooperation with interested Asian countries, is creating two important financial development institutions: the Asian Infrastructure Investment Bank and the Silk Road Fund. The new Chinese initiative, judging by the available information available, can pursue three strategic objectives:

expansion of international and regional trade; the creation of international transport corridors from China to Europe and the Middle East through the territory of Kazakhstan and Central Asia;

gradual increase of China's economic presence in Central Asia as a strategically important partner. Kazakhstan, as well as other countries of Central Asia, it is important to participate in the implementation of the Chinese EEPS initiative, to effectively use the emerging new opportunities and advantages of regional cooperation, while achieving, at the same time, minimizing risks and threats.
\end{abstract}

Citation: Tleulina Aigerim. (2020) Development of Cooperation Between Central Asian Countries and China in Accordance with the "Economic Belt of Silk Road". International Journal of Innovative Technologies in Economy. 1(28). doi: 10.31435/rsglobal_ijite/31032020/6964

Copyright: (C) 2020 Tleulina Aigerim. This is an open-access article distributed under the terms of the Creative Commons Attribution License (CC BY). The use, distribution or reproduction in other forums is permitted, provided the original author(s) or licensor are credited and that the original publication in this journal is cited, in accordance with accepted academic practice. No use, distribution or reproduction is permitted which does not comply with these terms.

Introduction. Nowadays, the great interest is the new Chinese initiative, which aimed at the revival of the Great Silk Road in modern conditions. This initiative opens up new opportunities and prospects for trade, economic and investment cooperation between the countries along the Silk Road, including Kazakhstan. Moreover, for the practical implementation of its initiative, China is creating such new development financial institutions as the Asian Infrastructure Investment Bank and the Silk Road fund, whose capitals will be used to implement infrastructure projects.

On September 16, 2013, speaking at the Nazarbayev University in Astana, President of the People's Republic of China Xi Jinping expressed the idea of creating the "Economic belt of the Silk Road" as a new form of deepening cooperation between China, the states of Central Asia and Russia. This idea caused a powerful resonance not only among politicians and political scientists, but also in the community of economists and experts, since the leader of China first put forward a foreign policy initiative that affects the prospects for economic development of the whole continent - Eurasia. Over the past time, the initiative has become not just a concept, but a major international project of great economic interest not only for China itself, but for all countries along the Great Silk Road, including the Republic of Kazakhstan.

The Economic belt of the Silk Road project (hereinafter referred to as the "EBSR") has formed China's new long-term strategy "One belt - one way". 
The new Chinese initiative, judging by the available information available, can pursue three strategic objectives:

- expansion of international and regional trade;

- the creation of international transport corridors from China to Europe and the Middle East through the territory of Kazakhstan and Central Asia;

- gradual increase of China's economic presence in Central Asia as a strategically important partner

To achieve these goals, the key tasks for China are:

- development of trade and economic cooperation, removal of numerous barriers and restrictions in international and mutual trade, creation of a favorable climate for investment inflow;

- the construction of the Eurasian transcontinental network of railways and highways, which allows the flexible use of various international transport corridors;

- comprehensive deepening of China's trade, economic, transport and logistics links with countries along the Silk Road, primarily with the countries of Central Asia;

- connect all the links of the Great Silk Road with the help of advanced transportinfrastructure and communication networks, as well as the development of a pipeline system;

- expansion of exports of Chinese goods, according to which China has excess production capacity within the country, primarily in its western provinces (overproduction of steel, aluminum, photoelectric equipment, wind generators, etc.);

- the conduct of mutual settlements between Silk Road participants using different currencies.

\section{Countries along the Silk Road.}

The countries of Eurasia along the Silk Road (hereinafter referred to as the "SR") can be conditionally grouped into five regions, for each of which China in its initiative defines a specific role.

First of all, the Central Asian region, including Kazakhstan, Kyrgyzstan, Tajikistan, Uzbekistan and Turkmenistan, is designated as an outpost for expanding trade and economic ties with Europe, Russia, Turkey and Iran. Kazakhstan and Central Asia as a whole occupy an exceptionally important geostrategic position in Central Eurasia. These countries have treasures of precious metals, ore and metallurgical raw materials, energy resources.

The second region includes Iran, Iraq, Jordan, Syria, Saudi Arabia, Turkey and other countries of Western Asia. In this case, the energy of these countries ensures the production and export of oil and gas resources for China.

Azerbaijan, Georgia, Armenia in the Caucasus, Ukraine, Belarus, Moldova in Eastern Europe are in the third region located on the border of Asia and Europe. The countries of this region, due to their geo-economic location, were at the junction between the European Union and the Eurasian Economic Union.

Russia, due to the scale of its economy and its long geographical location both in Asia and in Europe, is reasonably considered by China as a separate economic region and an independent regional center. Historically, it is only partially located along the Silk Road. Russia, together with Kazakhstan, Belarus, Armenia and Kyrgyzstan, is currently engaged in the formation of the Eurasian Economic Union. Moreover, due to the historical situation, Russia closely cooperates with the countries of Central Asia, the Caucasus and Western Asia.

Afghanistan, Pakistan and India can also be identified in a separate region. Central Asia is the main goal of the Chinese EBSR concept, which provides for the modernization and construction of new railway lines, highways, pipelines and other infrastructure elements that promote the development of international and regional trade.

As expected, the main cargo flow by EBSR will be from the East to the West (Fig. 2). Western and central provinces of China due to the newly created international transport corridors will be on direct rail communication with the EU countries along the route through the station Dostyk (Kazakhstan).

By 2035, China, according to the forecast of British Petroleum, will become the largest consumer of oil in the world, pushing the United States. For twenty years, the demand for oil $(0.8 \%$ per year) will grow more slowly than the demand for gas (1.9\%). Half of the increase in demand for gas will be covered by supplies from Russia and the Middle East, the other half - shale gas supplies. Therefore, China will pay more attention to the pipelines in Central Asia, passing through the territory of Kazakhstan.

With a view to the practical implementation of the EBSR initiative, China, in cooperation with interested Asian countries, is creating two important financial development institutions: the Asian Infrastructure Investment Bank and the Silk Road Fund. 


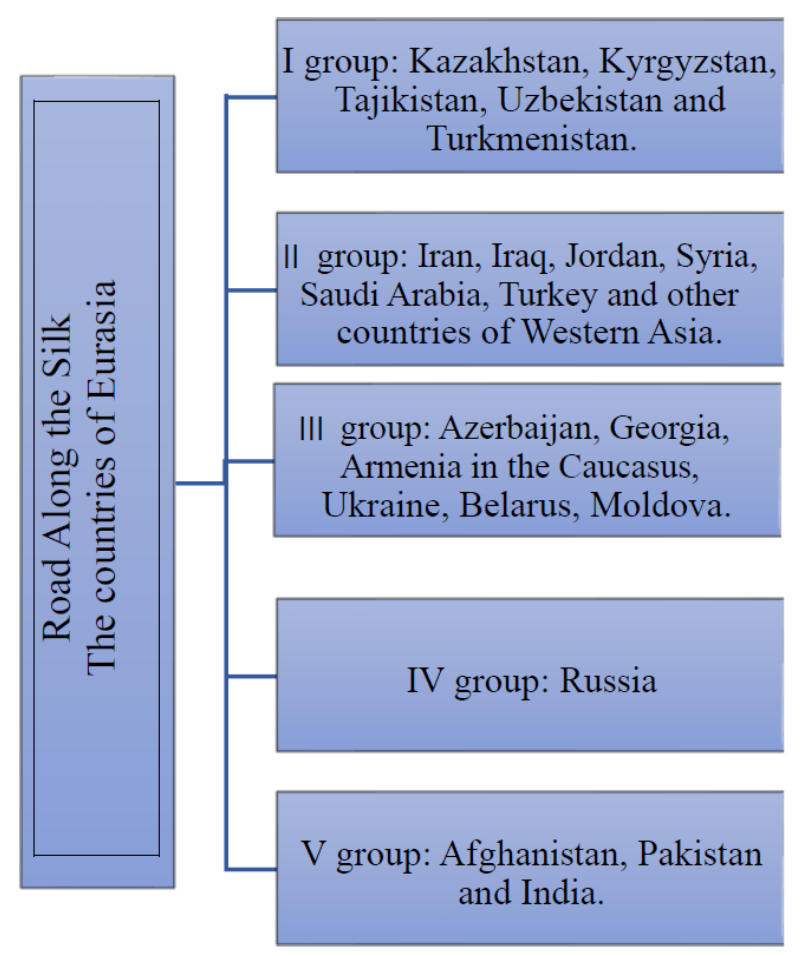

Fig. 1. Countries along the SR

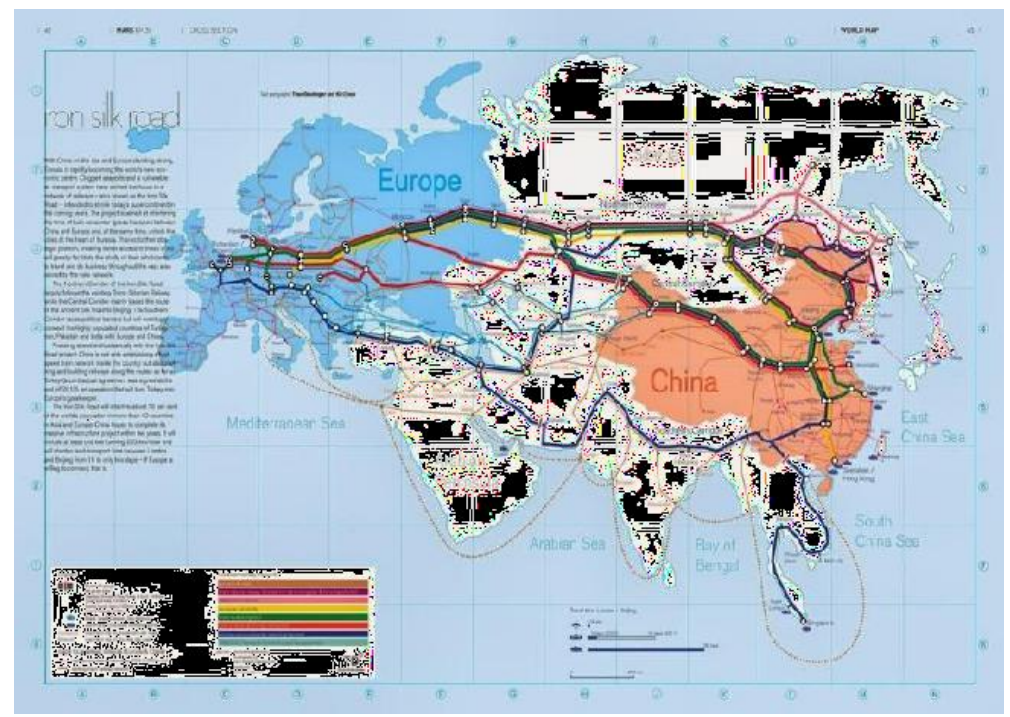

Fig 2. The railway line of the "Economic Belt of the Silk road"

Access to the domestic markets of Kazakhstan and Kyrgyzstan will allow Chinese companies and banks to simultaneously enter the common markets for goods, services, capital and labor of the Eurasian Economic Union. At present, the Silk Road Economic Belt and Maritime Silk Road Economic Belt Strategy is one of the largest initiatives, which has fundamentally changed the face of the modern world and formed a new paradigm for economic and general geostrategic development.

Today, China is the leading force in Central Asia and has the potential to influence the global vision of mankind. China is becoming a non-traditional superpower representing all aspects in different regional backgrounds, and it is also a major investor and trading partner of Central Asian countries. Kazakhstan is the important and largest market for China in the CIS region, second only to Russia. The level of development of Kazakh-China economic and trade relations is more dynamic. Effective foreign trade policy, utilization of resource potential in the industrial sector, modernization, technological potential-all these have led to the rapid development of the Kazakh economy. As mentioned earlier, the further development of the Eurasian transport corridor has opened a new 
milestone in Sino-Kazakh cooperation, providing a direct link between China's "Belt and Road Initiative" mega project, Kazakhstan's new economic policy "Nuri Zell" and the Eurasian Economic Union. The Eurasian Integrated Transport system project will create mature transport and logistics corridors, which will promote trade relations among countries along the corridor.

At the same time, the development of Eurasian transport corridors will solve some of the economic and social problems in the areas attracted by the project. Kazakhstan has enough potential to become a major transportation hub in Eurasia. The geographical location of the Republic makes it possible for it to become a major transit hub between Europe and Asia and a major partner of China in the region.

Today, there are five international transport corridors in Kazakhstan (MTK), which greatly shortens the distance and time for the delivery of goods compared with maritime corridors:

The Trans-Asian Railway Corridor: the north (Western Europe-China, Japan, South Korea) and the south (South-East Europe-China-Southeast Asia); The Central Asian Corridor (Central AsiaRussia and EU countries); North-South Corridor (Nordic-Gulf States); Europe-Caucasus-Asia International Transport Corridor (TRACECA).

TRACECA is a multimodal transport system for the countries of the region and its purpose is to develop trade and economic relations as well as transport links between countries and regions. Today, TRACECA includes the transport systems of 13 member countries of the basic multilateral agreement on international transport development in the Europe-Caucasus-Asia corridor. The corridor originated in Eastern European countries (Bulgaria, Moldova, Romania, Ukraine) and also passed through Turkey.

Then cross the Black Sea to the ports of Poti and Batumi in Georgia, and then to the transport network of Iran's South Caucasus countries, using land links from Turkey to the region. From Azerbaijan, through the Caspian Sea ferry crossing points (Baku-Turkmenistan Bash, Baku-Aktau), TRACECA route) to the railway networks of the Central Asian countries (Central Asia)-Turkmenistan and Kazakhstan, the transport networks of these countries are connected to the destinations of Uzbekistan, Kyrgyzstan and Tajikistan and border with China and Afghanistan, while Central Asian countries are connected by land and sea to Iran.

At the same time, the Route Coordination Committee includes JSC "Azerbaijan Railway", JSC "Georgia Railway", JSC "State Company", "NC" KTZ "of Kazakhstan", CJSC "Azerbaijan Caspian Shipping Company", JSC "State Company", "Aktau International Maritime Trade Port", Baku International Maritime Trade Port and LLC "Batumi Seaport".

According to the forecast of experts, the transit freight volume from China to TRACECA countries may increase from 1.5 million tons to 5 million tons in the medium to long term. The priority areas of action for TRACECA countries to develop the Europe-Caucasus-Asia corridor are set out in the Intergovernmental Committee (MMA) TRACECA Strategy for 2016-2026. At the same time, the main obstacles to trade and transport along the TRACECA Corridor are cumbersome import and export procedures, lack of coherence among member States and lack of funds. The regulatory environment for general business and corruption at border crossings have led to continuous delays in vehicles at border crossings. The MMA TRACECA strategy provides solutions to existing problems. The trans-Caspian Sea route Silk Wind ("Silk Wind") was developed at the end of 2012 within the framework of TRACECA.

In 2014, Kazakhstan, Azerbaijan, Georgia, Turkey and China established the Coordinating Committee for the Development of International Transport routes across the Caspian Sea ((CC TITC)). The results of the work of the members of the Coordinating Committee are as follows:

- Effective comprehensive freight rates for container transport and preferential rates for oil, natural gas, oil and grain transport;

- China-Kazakhstan-Azerbaijan-Georgia-Turkey railway and maritime transport companies involved in international rail and ferry direct transport cooperation container train passage technology has been approved;

- To create a container service "nomadic express";

- He organized three pilot container trains "Nomadic Express".

- He launched an image campaign and a roadshow.

One of the main partners of the committee is the China Transportation Association. Subsequently, the composition of the Committee expanded at the expense of "Ukrzaliznytsia" and "Ukrferi" (Ukraine), TransLogistic (Moldova) and PKP LHS (Poland). The Coordinating Committee was later transformed into an association with the Hungarian ZRT (Hungary) of Railway Freight Transport. Ukraine and Lithuania then signed a joint memorandum with the TITC container train 
Viking, allowing EU countries to supply goods to China and Central Asia through the creation of free trade zones. In addition, container trains from the Baltic countries are planned to be launched through Black Sea ports and integrated with nomadic express trains in Central Asia and China. The most wellprepared work within the ITC is the infrastructure of Kazakhstan.

The thawed international maritime trading port Aktau is an important channel for import and export business in the Ural and Siberian regions. The above land transport corridor can shorten the delivery time of east-west routes. Today, the best way for Kazakhstan and China to establish mutually beneficial cooperation has been worked out (table 1).

Table 1. Kazakhstan is regarded as a major project as part of the "Belt and Road Initiative" project

\begin{tabular}{|l|c|c|}
\hline \multicolumn{1}{|c|}{ Plan } & Value, millions of dollar & Construction time \\
\hline The dry port "Horgos" & 222 & $2014-2020$ \\
\hline "Kuryk" port & 261 & $2015-2018$ \\
\hline "Zhezkazgan - Beinewu" railway & 1131 & $2012-2017$ \\
\hline "Arkalyk-Shubarkol" railway & 242 & $2012-2017$ \\
\hline "Almaty 1-Chu" railway & 102 & $2015-2017$ \\
\hline Nursultan new railway station & 561 & $2013-2017$ \\
\hline Shymkent logistic center & 43 & $2014-2017$ \\
\hline Nursultan logistic center & 82 & $2014-2016$ \\
\hline Modernization Construction of Aktau Port & 112 & $2014-2017$ \\
\hline
\end{tabular}

It should be noted that the Government of Kazakhstan is implementing a breakthrough project aimed at accelerating the development of Kazakhstan's transport and transit system.

One of the projects is the construction of an international transit highway corridor with a total length of $2700 \mathrm{~km}$, "Western Europe-Western China". St.Petersburg - Moscow - Niznii Novgorod - Kazan'Orenburg - Aktobe - Kyzylorda - Shymkent - Talas - Gurdai - Almaty - Horgos Urumqi - Lanzhou Zhengzhou - Lianyungang route has a total length of $8445 \mathrm{~km}$. Of these, $2333 \mathrm{~km}$ pass through Russian territory, $2787 \mathrm{~km}$ through Kazakhstan and $3425 \mathrm{~km}$ through Chinese territory. The project aims to establish an effective east-west route across Kazakhstan and to open direct transit routes for import and export goods and goods. The annual freight volume of the Kazakh section is expected to reach 30 million tons.

The route will connect China, Kazakhstan, Russia, Europe and Central Asian countries (Kyrgyzstan, Uzbekistan, Tajikistan). Compared with the existing alternative corridors (Transsib Highway, sea passage through the Suez Canal), the main positive indicators of the project are the length and duration of the journey.

If the maximum use time of the sea passage is 45 days and that of Waixi cloth is 14 days, then the travel time along the "Western Europe-Western China" passage is about 10 days. The project will provide freight in three main directions: China-Kazakhstan, China-Central Asia, and ChinaKazakhstan-Russia-Western Europe.

In 2014, Kazakhstan built the $1036 \mathrm{~km}$ Zhezkazgan - Benewu railway line, reducing the distance from East Kazakhstan to West Kazakhstan to $1000 \mathrm{~km}$, thus tripling the rail transport time in the Central European direction. It is planned to build a narrow-gauge road, Horgos - Aktau port. At the same time, the Kazakhstan-Turkmenistan-Iran railway line provides opportunities to reach the Persian Gulf countries and India, which enables goods from the central and western regions of China to be transported to these countries as soon as possible.

In order to improve the port's handling capacity, Aktau Port built a new dry cargo terminal in 2015 , increasing the port's handling capacity to 19.5 million tons. The terminal in the north of Aktogai is under construction and will increase the port's handling capacity by 3 million tons. In addition, in order to ensure the transhipment of transit goods and the development of Caspian Sea-to-Caspian Sea multimodal transport, a project to build a ferry complex at the port of Curique is being implemented. Overall, it is planned to increase the total handling capacity of the Kazakh seaport to 26 million tons by 2020, which will make it a strategic point for cargo transshipment in the direction of the Caspian Sea.

These projects develop a framework for the country's unified transport architecture and interfaces with regional and world trade corridors. In order to optimize trade, special economic zones have formed the "Horgos-East Gate" with developed production and service infrastructure. The main purpose of this facility is to provide services for import, export and transit cargo flows. In addition to industrial and logistics areas, the infrastructure of the SEZs also includes a dry port, which was 
launched in 2015 with the aim of integrating and distributing goods in the eastern part of the country. In addition, Kazakhstan is actively striving to build an internal terminal network by 2020 .

Each transport and logistics centre includes category A warehouses, refrigerated storage, vegetable storage, shelf storage, container areas, customs services and temporary storage warehouses. At the same time, services are provided in accordance with the principle of "one window".

In 2014, a logistics terminal was established with Chinese partners at Lianyungang Port, which is currently the main gathering point for cargo flows to and from / through Kazakhstan. The corridor is the shortest road route from China to Europe in 10 to 12 days (which is 3.5 times shorter than the traditional sea route through the Suez Canal). TLC's container processing capacity is expected to increase from 193000 pounds equivalent in 2015 to 550000 pounds equivalent by 2020. At the same time, LLC "Lianyungang Group" has a 51\% stake, and KTZ Express (a subsidiary of JSC "NC" KTZ "national transport logistics operator, created specifically for multimodal transport)-49\%. The cost of the project amounts to 99.3 million dollars. \$35.1 million, of which \$35.1 million was allocated to the fund. The United States has invested 33.7 million dollars in port services. KTZ express delivery, the rest by Chinese banks to grant credit. The dry port is technically connected with the two railway ports bordering China-the Jidigen-Colgas Railway and the Western Europe-Western China Highway, with the participation of major transport and logistics operators in charge, opening a new stage of transport development in Eurasia.

"Belt and Road" Initiative's largest logistics projects is a transcontinental project to build an Eurasian high-speed freight and passenger corridor (HSL Eurasia) linking China and Europe. The construction project of the Eurasian plant is currently the largest railway project in the world, with a total length of about $9500 \mathrm{~km}$, of which $6700 \mathrm{~km}(70 \%)$ will form a new railway line. The project is expected to create the largest high-speed transport network with a length of more than 50,000 kilometers by integrating the transport systems of Asia, Russia and EU countries. There will be 17300 kilometers of Eurasian railway in Kazakhstan.

The Eurasian project is scheduled to be completed in 2026. Different parts of the project will have different production dates. In 2018, the Russian-Chinese consortium began the construction of the first phase of the "Eurasian"-"Moscow-Kazan" project operating on Russian territory, which is scheduled to be put into production in 2023. The "Moscow-Kazan" project operating in Russia was started by the Russian-Chinese consortium in 2018 and is scheduled to be put into production in 2023. Under the JSC "Russian Railway" (RR) project, HSL "Eurasia" will contribute to the growth of mutual trade, deepen regional integration and increase the prosperity of the region as a whole. According to preliminary estimates by developer JSC Russian Railway, trade between China and EU countries is expected to more than double-from $\$ 632$ billion in 2016 to $\$ 135.6$ million in 2035. JSC Russian Railway also noted that in the first five years of the opening of the Eurasian plant, transport between China and Europe is expected to increase 3.3 times, or 5.9 million to 8.5 million tons per year. In addition, transit plans in these directions have increased to 16.6 million tons per year.

For the purpose of financing the highway "Eurasia" project, the project developers have provided a mechanism for combining state funds with funds from international financial organizations such as the Silk Road Fund, the BRICS Bank, the Eurasian Development Bank, and the Russia-China Foundation.

In order to implement the "Eurasian" project on the Russian side, a project was carried out to involve countries planning to build railway lines to form a new transport route along the historic Silk Road. So far, Russia has reached an agreement with Kazakhstan on the joint development of the project.

Therefore, in February 2018, JSC "Russian Railway" signed a memorandum of cooperation in the field of "Eurasian" highway development with JSC "NC" Kazakstan Temir Zholy (KTZ). Within the framework of the memorandum, an action plan for project implementation at the railway bureau level was formed, and Kazakhstan formulated the draft terms of reference for the feasibility study of highway construction projects according to the action plan. At the same time, it is worth noting that on the Kazakh side, an alternative route for the construction of the highway "Eurasia" has been provided.

With the participation of Azerbaijan, Georgia, Turkey, Ukraine, Romania and Poland, an international trans-Caspian Sea transport route across the territory of Kazakhstan was opened, and the Uzen-Berecit-Gogan railway line, as well as Turkmenistan and Iran, created unprecedented opportunities for access to new markets.

Compared with the sea, the land trans-European route connecting Europe and Asia has obvious competitive advantages. The completion of the construction of the Kars-Akhalkalaki railway section on the Turkish-Georgian border will give additional impetus to the development of the line. 
However, the potential of international transport routes across the Caspian Sea has not yet been fully realized. In this regard, it is necessary to recognize the potential of this route to serve the growing container flow from China. To create favorable conditions for increasing the flow of goods to ChinaEurope-China, up to 500000 20-pound equivalent containers will be allowed by 2020. One of the promising areas of cooperation is the construction of the Eurasian Canal (Caspian Sea-Azov-Black Sea Basin) to expand transit potential for the benefit of Kazakhstan, Russia, China and Caspian Sea countriesTurkmenistan, Iran and Azerbaijan. This could be an effective corridor for the entire Central Asian region to reach the sea through Russia. In order to prove the economic feasibility of building an Eurasian corridor, experts assessed the transit goods that may flow from China to Europe through Kazakhstan and Russia by 2050. Two options are calculated: no existence of the Eurasian Strait and during its construction.

According to scientists, before the construction of the Eurasian corridor in 2030, the volume of Chinese cargo passing through Kazakhstan and further through Russia will be about 6.3 million tons, and when the channel is opened, it will reach 24 million to 30 million tons.

Before the construction of the Eurasian Canal in 2050, the volume of Chinese cargo through Kazakhstan and further through Russia will be about 12.9 million tons, and after the opening of the channel-43 million tons to 51 million tons.

The "Sinogidro" Chinese company has determined the volume of China's export cargo flow, which is likely to be transported from east to west through the Eurasian Strait. According to 2015 estimates, by 2030, 18 million - 30 million tons of goods will be transported through Eurasian waterways in 2030 and 34 million-44 million tons of Chinese exports in 2050.

Kazakh and Chinese companies are willing to participate in the financing of this channel construction on an equal footing. The project to create a multimodal transport corridor the Eurasian Trans-Continental Corridor will promote the development of transit potential and international transport and communication flows. The implementation of the project will facilitate the smooth shipment of goods from Asia to Europe.

The transport corridor will pass through:

1. Through Kazakhstan, Russian territory and further to Europe (within the framework of combined transport and logistics companies);

2. From Horgos through the territory of Kazakhstan to the port of Aktau, then along the Caspian Sea to Azerbaijan, then within the framework of the Coordinating Committee through Georgia (China, Turkey), the agreement on "north-south" international transport corridors (Turkmenistan, Iran, India, Middle East countries) and international corridors TRACECA (Georgia, Azerbaijan, Turkey).

In order to implement this initiative, a national legal framework for the development of multimodal transport (intermodal transport, multimodal transport) has been established, in particular:

- Container transport is not subject to the state control of the natural monopoly of the Republic of Kazakhstan;

- Domestic shipping companies are exempted from enterprise income tax;

- Cars are granted tariff exemptions to avoid a shortage of EU IV and above vehicles used in international transport.

In order to further develop cooperation between countries, it is necessary to improve the quality of transport infrastructure and reduce tangible and intangible obstacles, namely:

- Customs procedures at borders (ports) should be accelerated and simplified to bring them in line with the international conventions signed by TRACECA countries;

- The pre-declaration system should be implemented;

- Port procedures (ship berthing and loading and unloading planning, cargo storage monitoring, port information system) need to be improved;

- Electronic booking must be made in advance, which is a kind of ship prepayment system.

It is necessary to implement complex forms of tariff payment for multimodal transport, so that customers can easily obtain transparent door-to-door customs duties. Located in the heart of Eurasia and between the poles of the world economy, Kazakhstan attaches particular importance to the development of transit potential.

Today, a strategic transport corridor connecting the north and south of Eurasia and Eurasia has been built. More than 15 container transit routes between China and Europe pass through Kazakhstan. In the long run, the Eurasian transport route through Kazakhstan will become an efficient route from China to Europe. This will create favorable conditions for the large-scale development of the western 
region and the development of trade and logistics in the central region, and have a positive impact on the "international multimodal transport" of China-EU trade.

Commodity turnovers of Kazakhstan with major trading partners. Correlationregression analysis between the volume of commodity turnovers $(y)$, the volume of imports $(x 1)$ and the volume of exports (x2)

China is Kazakhstan's largest trading partner in Asia, and Kazakhstan ranks second among China's trade partners in the CIS after Russia.

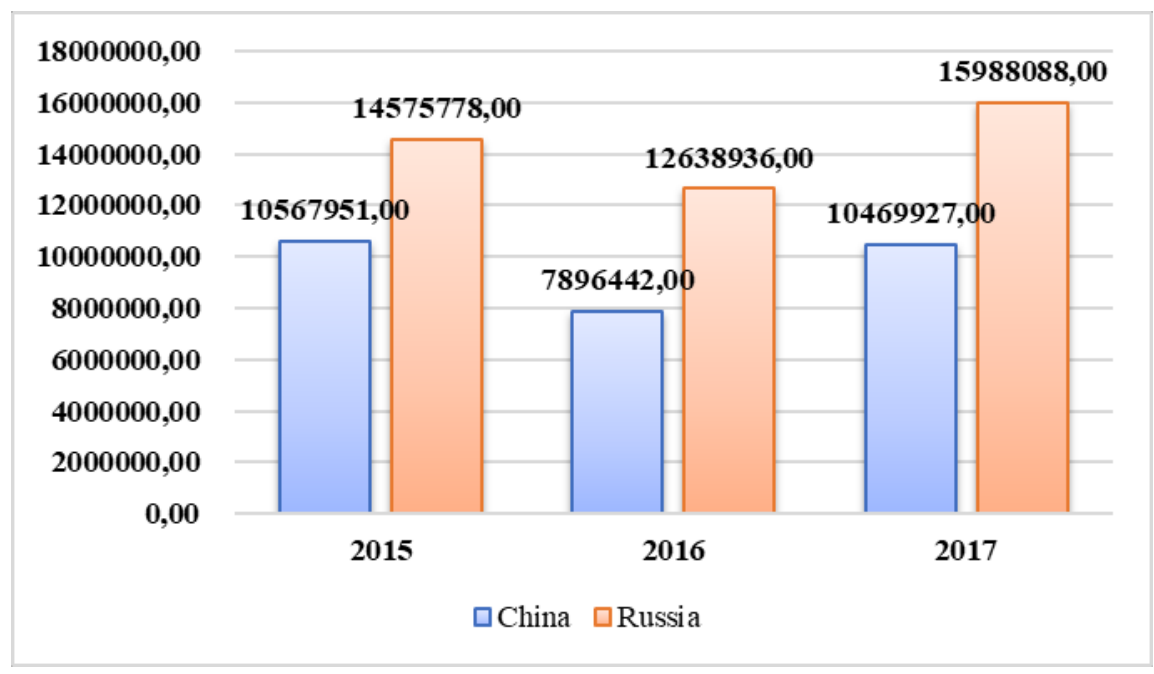

Fig. 3. The commodity turnovers of the Republic of Kazakhstan with major trading partners

The commodity turnovers of the Republic of Kazakhstan with the main trading partners such as Russia and China in 2017, according to calculations based on the data of the Committee on Statistics of the Ministry of National Economy of the Republic of Kazakhstan, concluded to 26458 015,2 thousand US dollars (Fig.3), of which 15,988,088 thousand USA dollars - Russia, 10469927,13 thousand US dollars China. The growth rates for China in $2016-2017$ years is $32,59 \%$, Russia $-26,5 \%$ respectively.

Correlation-regression analysis is performed to determine the degree of correlation between the result and the factors influencing the result.

The analysis of the influence of factors on the volume of commodity turnover (y) is carried out according to the following data: the volume of imports (x1) and the volume of exports (x2). To begin with, it is necessary to determine the nature of the relationship between the symptoms and establish a form of communication between them.

Indicators for commodity turnover, imports and exports between China and Republic of Kazakhstan are presented in table 2.

Table 2. Commodity turnover, exports and imports between China and Republic of Kazakhstan

\begin{tabular}{|c|c|c|c|}
\hline Year & The commodity turnovers, Y & Import, X1 & Export, X2 \\
\hline 2013 & 22738200,0 & 8364500,0 & 14373700,0 \\
\hline 2014 & 17156600,0 & 7357200,0 & 9799400,0 \\
\hline 2015 & 10567950,9 & 5087813,4 & 5480137,5 \\
\hline 2016 & 7896442,2 & 3668032,2 & 4228410,0 \\
\hline 2017 & 10469927,1 & 4692242,4 & 5777684,7 \\
\hline
\end{tabular}

As a result of the construction of the correlation matrix by means of MS Exsel we obtain the following data (table 3).

Table 3. Correlation matrix

\begin{tabular}{|l|c|l|l|}
\hline & The commodity turnovers, Y & Import, X1 & Export, X2 \\
\hline $\begin{array}{l}\text { The commodity } \\
\text { turnovers, Y }\end{array}$ & 1 & & \\
\hline Import, X1 & 0,984374208 & 1 & \\
\hline Export, X2 & 0,996579319 & 0,966454653 & 1 \\
\hline
\end{tabular}

Data on regression analysis for commodity turnover, export and import are presented in table 4. 
Table 4. Regression analysis for commodity turnover, export and import

\begin{tabular}{|l|c|}
\hline & Regression statistics \\
\hline Multiply R & 1 \\
\hline $\mathrm{R}^{\wedge} 2$ & 1 \\
\hline Standardized $\mathrm{R}^{\wedge} 2$ & 1 \\
\hline Standard Error & $9,95504 \mathrm{E}-10$ \\
\hline Observations & 5 \\
\hline
\end{tabular}

\begin{tabular}{|l|c|c|l|l|l|}
\hline \multicolumn{2}{|l|}{ Dispersion analysis } & \multicolumn{1}{l|}{ SS } & MS & F & $\begin{array}{l}\text { The } \\
\text { significance } \\
\text { of F }\end{array}$ \\
\hline Regression & 2 & $1,48 \mathrm{E}+14$ & $7,38 \mathrm{E}+13$ & $7,44 \mathrm{E}+31$ & $1,34 \mathrm{E}-32$ \\
\hline Balance & 2 & $1,98 \mathrm{E}-18$ & $9,91 \mathrm{E}-19$ & & \\
\hline Total & 4 & $1,48 \mathrm{E}+14$ & & & \\
\hline
\end{tabular}

\begin{tabular}{|l|c|c|c|c|c|c|c|c|}
\hline & Coefficients & $\begin{array}{c}\text { Standard } \\
\text { Error }\end{array}$ & t-statistics & P-value & $\begin{array}{c}\text { Lower } \\
95 \%\end{array}$ & $\begin{array}{c}\text { Upper } \\
95 \%\end{array}$ & $\begin{array}{c}\text { Lower } \\
95 \%\end{array}$ & $\begin{array}{c}\text { Upper } \\
95 \%\end{array}$ \\
\hline $\begin{array}{l}\text { Y- } \\
\text { intersection }\end{array}$ & $-4,65661 \mathrm{E}-09$ & $2,45 \mathrm{E}-09$ & $-1,89858$ & 0,198034 & $-1,5 \mathrm{E}-08$ & $5,9 \mathrm{E}-09$ & $-1,5 \mathrm{E}-08$ & $5,9 \mathrm{E}-09$ \\
\hline Import, X1 & 1 & $9,92 \mathrm{E}-16$ & $1,01 \mathrm{E}+15$ & $9,84 \mathrm{E}-31$ & 1 & 1 & 1 & 1 \\
\hline Export, X2 & 1 & $4,65 \mathrm{E}-16$ & $2,15 \mathrm{E}+15$ & $2,17 \mathrm{E}-31$ & 1 & 1 & 1 & 1 \\
\hline
\end{tabular}

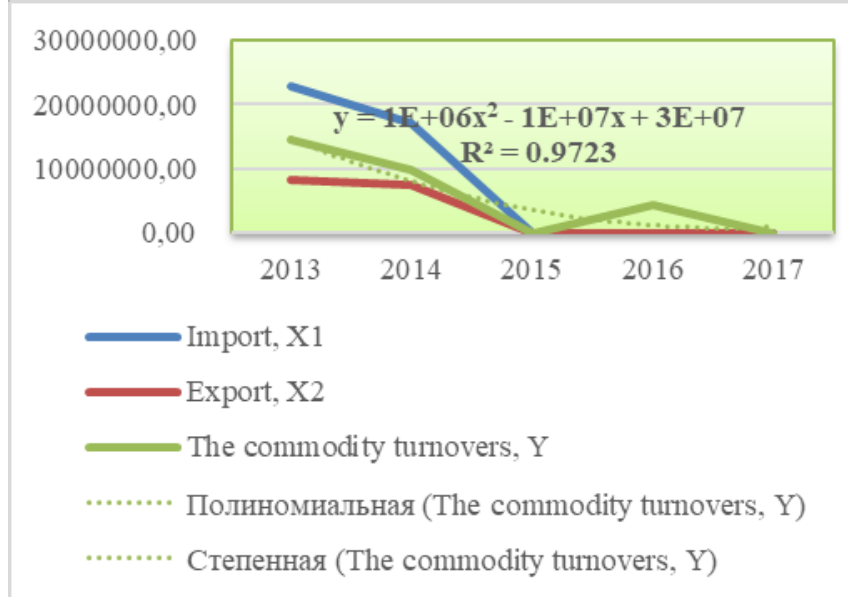

Fig. 4. Commodity turnover, exports and imports between China and Republic of Kazakhstan As a result of the solutions of the equation in MS Excel, the following parameters were obtained:

$$
\mathrm{Y}=-4.65661 \mathrm{E}-09+1 * \mathrm{X} 1+1 * \mathrm{X} 2 \text {, }
$$

Integration of the obtained parameters should be:

A $0=-4.65661 \mathrm{E}-09-$ the conditional beginning of a meaningful interpretation is not subject to;

A $1=1-$ coefficient of pure regression at the first factor;

A $2=1-$ pure regression coefficient for the second factor.

The coefficient of multiple correlation is 1 , it indicates that the connection is very strong.

Conclusions. Kazakh-Chinese trade and economic relations were developed on the basis of important and numerous inter-State and intergovernmental treaties and agreements defining the basic principles and directions of mutually beneficial cooperation between the Republic of Kazakhstan and the people's Republic of China.

Silk Road Economic belt (Silk Road Economic belt) opens up new opportunities for economic development, brings stability and security.

The mutual interest of the leaders of the ESDP project is expressed in the willingness to create a common security space based on partnership, political dialogue, which can counter external threats of various kinds. 
At present, China is the dominant force and has the potential to influence the global vision of mankind.

China is becoming a non-traditional superpower, representing various aspects in different regional contexts, as well as a key player in Central Asia as the main investor and leading trading partner for the countries of the region.

Kazakhstan is an important and largest market for China in the CIS area after Russia. The level of development of trade and economic ties between Kazakhstan and China is becoming more dynamic.

Effective foreign trade policy, use of resource potential of the industrial sector, modernization, technological potential-all this led Kazakhstan to rapid development of the economy. The implementation of the EBSR project in the long term will improve the transport infrastructure, provide Kazakhstan's access to the seaports of the countries participating in the Silk Road, accelerate the delivery of Kazakhstan goods to world markets, increase external and mutual trade, reduce costs for domestic exporters, including through the elimination of trade barriers and restrictions, attract new investments and joint projects.

At the same time, the formation of EBSR will be restrained due to the existing differences in the level of socio-economic development and living standards of countries located along the SR, the inadequate development of the transport and logistics infrastructure in Central Asia, the poor level of transport and forwarding services, the low efficiency of using rolling stock, the unwillingness of local businesses to compete internationally and enter foreign markets.

One of the threats for Kazakhstan may be the preservation of the raw material orientation of the national economy, since the investment projects of Chinese companies are primarily related to the extraction of oil and natural gas. So, over the past few years, 24.6 billion investments from China, more than $\$ 17.3$ billion were invested in the extraction of hydrocarbon raw materials, $\$ 6.2$ billion in the construction of trunk oil pipelines. Other threats include strengthening China's trade, economic and migration expansion to the Kazakhstan market, increasing dumping by Chinese enterprises, priority hiring of Chinese at enterprises created by China in Kazakhstan, increasing unemployment, deteriorating trade balance, increasing contraband, increasing competition for Kazakhstan enterprises, deterioration of the environment, etc.

The revived Great Silk Road on the basis of modern transport infrastructure and communications is able to ensure the rapid advancement of goods, services, capital and labor between Europe and Asia, as well as between countries along the Silk Road.

Kazakhstan, as well as other countries of Central Asia, it is important to participate in the implementation of the Chinese EEPS initiative, to effectively use the emerging new opportunities and advantages of regional cooperation, while achieving, at the same time, minimizing risks and threats.

In the same year, Kazakhstan adopted a five-year National Infrastructure Development Programme, which aims to improve domestic infrastructure to "ensure long-term economic growth in Kazakhstan". According to the law, within five years, Kazakhstan will give priority to the development of domestic transport and logistics infrastructure, especially as part of the trans-continental corridor, namely the Western Europe-China Western Corridor, and "continue to establish logistics centres in the east and maritime infrastructure in the west". Kazakhstan must therefore complete the construction of the centre-south-east-west roads by the end of the "five years", which will establish "ray links" between the capital and important areas of the country.

Therefore, the goals and objectives of Kazakhstan are in line with China's development strategy. China and the Republic of Kazakhstan launched the "Belt and Road Initiative" and "Nserrajul Road" connection project in 2016, and work on the construction of transport and logistics infrastructure in China and Kazakhstan is under way.

In addition, according to the strategies of Kazakhstan and China, the two sides must take all measures to "develop transit transport corridors, establish logistics centres in Kazakhstan and simplify procedures (customs, taxation, finance, etc.). In order to expand mutual trade", this will also enable Chinese products to enter the European and Middle East markets more quickly. Kazakhstan accounts for a large share of the trade between China and the West. As a result, by 2020, it is expected that more than 3000 container trains from China or China will pass through Kazakh territory as part of the "Belt and Road Initiative" and "Nurly Zhol" strategic link plan.

Despite the shortcomings in transport cooperation between China and the Republic of Kazakhstan, despite the implementation of the "Belt and Road Initiative" revitalization plan, this project is promising and useful. And the problems that must be solved quickly in order to successfully implement the China-Kazakhstan strategic interface plan. 
In short, Sino-Kazakh logistics cooperation has been booming for a long time, and even now, there is still room for bilateral relations between the two countries to expand. In addition, so far, the implementation of the China-Kazakhstan logistics project has reached the international strategic level. This not only enables the two countries to develop backward areas where road and rail routes are located, but also through Kazakhstan, a country regarded as a transit transport hub, this enables China to independently develop faster, more reliable and promising access to the European market, while partly freeing itself from the import and export dependence on less efficient maritime routes.

For Kazakhstan this is an opportunity to modernize and integrate its transport system with the international transport system and stabilize its economy through China's investment and payment of goods transit costs.

In addition, although the problems and difficulties have yet to be solved together, but the implementation of the Kazakhstan-China strategic interface project, which has long been building largescale transport infrastructure in China and the Republic of Kazakhstan, will enable countries far apart to transport goods, resources and others quickly and without difficulty. It also helps to establish a "huge free trade area" in China's northwest provinces, from Central Asia to Central and Eastern Europe.

In conclusion, it should be noted that Kazakhstan was chosen for the purpose of promulgating the concept of the "Economic belt of the Silk Road". The leadership of China regards Kazakhstan as the main and prospective trade and economic partner in Central Asia. Moreover, Kazakhstan has the largest economy in the region and accumulates more than $70 \%$ of China's trade turnover with Central Asian countries. Expansion of mutually beneficial trade, economic and investment cooperation of countries along the ancient Silk Road will lead to the transformation of Central Eurasia into a region of strategic stability, political security and economic progress.

\section{REFERENCES}

1. N. Nazarbayev's message to the people of Kazakhstan. 11.11.2014 «Nurly Zhol -The way to the future» // http://www.akorda.kz/en/page/page_218341_poslanie-prezidenta-respubliki-kazakhstan-n-nazarbaevanarodu-kazakhstana-11-noyabrya-2014 -g

2. N. Nazarbayev's concluding remarks at the 25th meeting of the Council of Foreign Investors. 22.05.2012 г. // http://www.akorda.kz/en/page/zaklyuchitelnoe-slovo-prezidenta-respubliki-kazakhstan-nazarbaeva-n-a-na25-m-zasedanii-soveta-inostrannykh-in\#page

3. Xi Jinping's speech at the Nazarbayev's University (full text) // http://kz.china-embassy.org/eng/zhgx/t1077192.htm

4. World Bank // http://www.worldbank.org

5. World Trade Organization // https://www.wto.org

6. Amrebaev A. Economic belt of the Great Silk Road: from idea to reality // Kazakhstan in global processes. - 2014. - No. 3. - P. 30-39. Committee on Statistics of the Ministry of National Economy of the Republic of Kazakhstan // http://www.stat.gov.kz7.

7. Bugayenko A. Economic belt of the Silk Road: goals and prospects // Kazakhstan in global processes. 2015. - No. 1. - P. 64-73 // http://iwep.kz/en/magazine/2015

8. Ordabaev A. Geopolitics of transport corridors in Central Asia. Institute of World Economy and Politics (IMEP) under the Foundation of the First President of the Republic of Kazakhstan - the Leader of the Nation. - Astana - Almaty, 2015. - 48 p.

9. "Kazakhstan and China in the context of regional cooperation: Nurly Zhol and the Economic belt of the Silk Road", International Round Table, February 11, 2015, Astana // http://iwep.kz/ru/sobytiya/2015-02- 13 / kazahstan-i-kitay-v-kontekste-regionalnogo-sotrudnichestva-nurly-zhol-i-ekonomicheskiy-poyas-shelkovogoputi-mezhdunarodnyy

10. Materials of the international conference "Creating Eurasia: The Economic Belt of the Silk Road", April 17, 2015, Astana // http://iwep.kz/en/kommentariy-eksperta/2015-04-21/sozdanie-evrazii-ekonomicheskiy-poyas-shelkovogo-puti

11. Leaders of the Russian Federation and China adopted a statement on the linkage of the EAEC and the Silk Road // RIA Novosti http://ria.ru/economy/20150508/1063353811.html\#ixzz3a1HjyJoW

12. Syroezhkin K.L. Do Kazakhstan need to be afraid of China: myths and phobias of bilateral relations: Monograph. - Astana-Almaty: IMEP under the First President's Fund, 2014. - 432 p.

13. China will transfer dozens of enterprises to Kazakhstan // http://tengrinews.kz/markets/kitay-perenesetdesyatki-predpriyatiy-v-kazahstan-266949/

14. Syroezhkin K. Economic belt of the Silk Road with Chinese characters // http://www.baiterek.kz/node/1350

15. 15 The Asian Bank for Infrastructure Investments is changing the alignment of forces in the global financial system // http://en.euronews.com/2015/04/21/world-spotlight-on-asian-infrastructure-investment-bank/

16. Chinese economist Shi Jianxin on the Asian Bank for Infrastructure Investment: the burden is heavy and the way is far. // http://russian.china.org.cn/exclusive/txt/2015-04/23/content_35399456.htm

17. Article in the Kazakhstan journal EFI. - 2015. - No. 1. - P. 91-99. 
18. Raimbekov Zh., Syzdykbayeva B., Zhenskhan D., Rakhmetulina Zh. The effectiveness of lo-gistics development and its impact on the economies of the countries along the Silk Road passing through Kazakhstan. Transport problems. [Электронный ресурc]. URL: https:// www. exeley.com/transport problems/ (дата обращения: 01.05.2019).

19. Dave B., Kobayash Y. China's silk road economic belt initiative in Central Asia: economic and security implications // Asia Europe Journal. - 2018. - № 3. - p. 267-281.- doi: 10.1007/s10308-018-0513-x.

20. Соколова О.Ю., Захарова С.В. Макроэкономические риски функционирования ЕАЭС // Бизнес и стратегии. - 2017. - № 2. - с. 73-76.

21. Casey Michel China Edging Russia out of Central Asia. The Diplomat. [Электронный pecypc]. URL: https://thediplomat.com/2014/11/ china-edging-russia-out-of-central-asia/ (дата обращения: 01.05.2019).

22. Kerr D. Strategic regionalism: central Asian and Russian perspectives on China's re-emer-gence // International Affairs. - 2010. - № 1. - p. 127-152. - doi: 10.1111/j.1468-2346.2010.00872.x.

23. Younkyoo Kim, Fabio Indeo. The new great game in Central Asia post 2014: The US "New Silk Road" strategy and Sino-Russian rivalry // Communist and Post-Communist Stud-ies. - 2013. - № 2. - p. 275-286. - doi: 10.1016/j.postcomstud.2013.03.005.

24. Shisong Zhu, Zhuo Zhang Does the economic openness promote the five Central Asian countries 'economic development? - the analysis based on the data of 1992-2011 // Економічний вісник університету. - 2015. - № 1. - p. 141-148.

25. Захарова С.В., Соколова О.Ю., Лысенко Е.И. Показатели развития внешней торговли Евразийского экономического союза. / Развитие международного торгового потенциала России: проблемы и перспективы. - Саратов: Изд-во ССЭИ РЭУ им. Г.В.Плеханова, 2016. - 31-41 с.

26. Salykova, L.N. An investigation of foreign trade policy and its impact on economic growth: the case of Kazakhstan (1991-2008). Doctor's thesis. Robert Gordon University, 2012

27. Государственная программа инфраструктурного развития «Нұрлы жол» на 2015-2019годы. [Электронный ресурc]. URL: http://www.akorda.kz/ ru/official_documents/ strategies_and_programs ( дата обращения: 05.05.2019).

28. Официальный сайт TRACECA. [Электронный ресурс]. URL: http://www.traceca-org. org/ru/traseka/ (дата обращения: 05.05.2019).

29. Транспортные коридоры Евразии: новые пути сотрудничества. [Электронный pecypc]. URL: http://www.kisi.kz/uploads/33/ files/KuXXVFLd.pdf (дата обращения: 05.05.2019).

30. One Belt \& One Road. Максимизация инфраструктурного потенциала. https://www.sk.kz/upload/iblock/ccb/ccba73e6c86acc6cb5368e8fc6 da760d.pdf

31. Как Казахстан развивает транзит из Китая и что ему мешает. https://forbes.kz/finances/markets/popast_vkoleyu_1/ (дата обращения: 05.05.2019).

32. Высокоскоростной грузопассажирский железнодорожный транспортный коридор «Евразия». [Электронный pecypc]. URL: http://www.hsrail.ru/ info/silkway/ (дата об-ращения: 05.05.2019).

33. Казахстан ждет результаты ТЭО проекта Евразийской BCM. [Электронный pecypc]. URL: https://abctv.kz/ru/news/kazahstan-zhdet-rezultaty-teo-proekta-evrazijskoj-vsm

34. Трансконтинентальный коридор «Западная Европа - Западный Китай» - новый путь в Европу: от мечты к реальности». [Электронный ресурc]. URL: http://www. silk-road.kz/info/69 (дата обращения: 05.05.2019).

35. ЕБР, Центр интеграционных исследований «Транспортные коридоры Шелкового пути: анализ барьеров и рекомендации по направлению инвестиций». https://eabr.org/upload/iblock/304/EDB-Centre_2018_Re-port50_Transport-Corridors_Barriers-and-Investments_RUS.pdf (дата обращения: 05.05.2019).

36. Закон РК «О внесений изменений и дополнений в некоторые законодательные акты РК по вопросам налогообложения и таможенного администрирования» от 3.12 .2015 года № 432-V ЗРК. https://online.zakon.kz/ document/?doc_id=35287197\#pos=1;-155 ( дата обращения: 05.05.2019 ).

37. Приказ Министра национальной экономики Республики Казахстан от 27.11.2015года №737. [Электронный ресурc]. URL: http://adilet.zan.kz/ rus/origins/ V1500012832

38. Липин А.С. Углубление взаимодействия в рамках проведения согласованной макроэкономической политики в ЕАЭС. [Электронный ресурс] // выступление на Х международной конференции ЕАБР. - 29 октября 2015 - ЕАБР http://www.eabr.org/general/upload/10_Conference/Presentation/Andrey_Lipin.pdf

39. Султанов Б.К. Евразийская интеграция: от Таможенного союза до объединённого евразийского пространства: планы и реалии/ Б.К. Султанов/ сборник материалов научной конференции Интеграционные проекты в Евразии: проблемы социально-экономического развития. - Алматы, 2015. - С. 24-39. 16420.

40. Султанов Б.К. Евразийский экономический союз: Факторы интеграции и дезинтеграции / Б.К. Султанов/ сборник научных трудов Евразийская интеграция. - Санкт-Петербург, - 2014. -С. 150-155

41. Винокуров Е.Ю. Международные транспортные коридоры ЕврАзЭС: быстрее, дешевле, больше / Е.Ю. Винокуров, М.А. Джадралиев, Ю.А.Щербанин // ЕАБР. - Санкт-Петербург, - 2009. - 60 с.

42. N. Popescu Eurasian Union: the real, the imaginary and the likely / Nicu Popescu. [Electronic resource] // EU Institute for Security Studies. -2014 - P. 48. - Mode of access: http://www.iss.europa.eu/uploads/media/CP_132.pdf

43. Спартак А.Н. Перспективы евразийской экономической интеграции / А.Н. Спартак // Международная экономика. 
44. Фёдоров Л.С. Коридоры для Евразийского экономического союза / Л.С. Фёдоров, И.Х. Сабитов // Мир транспорта. - 2015. - №4(13). - С. 200-208.

45. Резер А.В. Методология управления интегрированными транспортнологистическими системами. автореферат на соиск. учён. степ. док. эк. наук (08.00.05) / Резер Алексей Владимирович, Московский государственный университет путей и сообщений (МГУПС). - Москва, - 2015. - 48 с.

46. Пустохина И.В. Организация и управление цепями поставок в логистических кластерах. дис. на соиск. учён. степ. канд. эк. наук (08.00.05) / Ирина Валерьевна Пустохина, Государственный университет управления. - Москва, 2015. - 172 с.

47. Саркисов С.В. Международные логистические системы в условиях глобализации. дис. на соиск. учён. степ. док. эк. наук (08.00.14) / Сергей Васильевич Саркисов, Академия народного хозяйства (АНХ) при Правительстве Российской Федерации. - Москва, - 2008. - 368 с.

48. Вань Цинсун Высшее благо подобно воде. [Электронный ресурс] / Вань Цинсун // Россия в глобальной политике. - 2016. - №1. - Режим доступа: http://globalaffairs.ru/number/vysshee-blagopodobno-vode-17939

49. Винокуров Е.Ю. Две евразийские интеграции / Е.Ю. Винокуров, А.М. Либман // Вопросы экономики. - 2013. - №2. - С. 47-72.

50. Зиядуллаев Н.С. Формирование Евразийского экономического союза: риски и шансы в период турбулентности / Н.С. Зиядуллаев // Российский внешнеэкономический вестник. - 2014. - №5. - С. 3-17.

51. Вардомский Л.Б. Новый проект евразийской интеграции стартовал: что дальше? /Л.Б. Вардомский, Л.3. Зевин // Общество и экономика. - 2013. - №1-2. - С. 40-56.

52. Глазьев С. Ю. Евразийская интеграция - ключевое направление политики / С.Ю. Глазьев // Журнал «Изборский клуб». - 2014. - №3(14). - С. 44-58.

53. Сергеев В.И. Общие тенденции развития логистических центров за рубежом / В.И. Сергеев // Логистика и управление цепями поставок. - 2012. - №5. - С. 7-18. - Режим доступа: http://lscm.ru/index.php/ru/po-godam/item/1177

54. Скриба А.С. Сопряжение ЕАЭС и Экономического пояса Шёлкового пути: интересы участников и вызовы реализации // А.С. Скриба // Вестник международных организация. - 2016 - №3 (11). - С. 67-79.

55. Dragneva R. Russia, the Eurasian Customs Union and the EU: Cooperation, Stagnation or Rivalry? / Rilka Dragneva, Kataryna Wolczuk. [Electronic resource] // Russia and Eurasia Programme. - 2012. - Mode of access: https://www.chathamhouse.org/sites/files/chathamhouse/public/Research/Russia\% 20 and\%20Eurasia/0812bp_dragnevawolczuk.pdf 118. 